Pre-print. Please cite published version.

\title{
The Equal Weight argument against religious exclusivism
}

\author{
Samuel Ruhmkorff \\ Bard College at Simon's Rock
}

\begin{abstract}
In the last decade, analytic epistemologists have engaged in a lively debate about Equal Weight, the claim that you should give the credences of epistemic peers the same consideration as your own credences. In this paper, I explore the implications of the debate about Equal Weight for how we should respond to religious disagreement found in the diversity of models of God. I first claim that one common argument against religious exclusivism and for religious pluralism can be articulated as an Equal Weight argument. I then argue that to avoid this argument, religious exclusivists must reject Equal Weight. Next, I maintain that, while the exclusivist complaint that pluralism is self-undermining is incorrect, exclusivists can rightly object that the pluralist's Equal Weight argument is self-undermining. Thus both exclusivists and pluralists have an interest in rejecting Equal Weight. My final discussion is speculative: I suggest that the goals of those of pluralist persuasion might be better met by religious permissivism, the view that some forms of both exclusivism and pluralism are rational responses to religious disagreement.
\end{abstract}




\title{
The Equal Weight argument against religious exclusivism
}

\author{
Samuel Ruhmkorff \\ Bard College at Simon's Rock
}

\section{Introduction}

The consideration of the diversity of models of God has led to a vast literature on the proper reaction to religious disagreement. Broadly speaking, there are three main positions. Exclusivism is the view that one model of God - presumably one's own - is correct and the others are incorrect to the extent that they are inconsistent with it. Inclusivism is the view that more than one model of God has access in some way to ultimate reality, although one model (again, presumably one's own) is uniquely positioned in respect to that reality. Pluralism is the view that more than model of God is correct in some important sense, and that no model enjoys a special status in relation to ultimate reality. I take the most economical and precise definition of these positions to be Schmidt-Leukel's. On his view, exclusivism, inclusivism, and pluralism are different answers to the question: how many religions possess the property of "[mediating] salvific knowledge of ultimate/transcendent reality (P)"? (Schmidt-Leukel 2005, 19):

1. Exactly one.

2. More than one, with a "singular maximum."

3. More than one, without a singular maximum.
Exclusivism

Inclusivism

Pluralism

In the last decade, analytic epistemologists have been inspired by the epistemological aspects of the debate about religious diversity (Kelly 2005, 173). A lively debate has arisen about the degree to which one's beliefs should be affected by learning that epistemic peers disagree with you. Elga and Christensen have defended Equal Weight, the claim that one should give the credences of epistemic peers as much consideration as one's own credences, and therefore adjust one's credences in response to learning of one's disagreement with one's peers. This debate has significant implications for how we should respond to religious diversity (see Thune 2010).

In this paper, I begin to explore these implications. I first claim that one common argument against exclusivism can be articulated as an Equal Weight argument. I then argue that, in order to avoid this argument, exclusivists must reject Equal Weight. Next, I maintain that the claim - puzzling to many - that pluralism is self-undermining is better interpreted as the claim that the Equal Weight argument is self-undermining. Thus both exclusivists and pluralists have an interest in rejecting Equal Weight. My final discussion is speculative rather than conclusive: I suggest that the goals of those of pluralist persuasion might be better met by abandoning Equal Weight and embracing Epistemic Permissiveness, the view that there is more than one rational response to a given body of evidence. Religious permissivism, a view based on Epistemic Permissiveness, has both hopeful and challenging implications for those responding to religious diversity. 


\section{Equal Weight}

What is the appropriate response to learning that an epistemic peer disagrees with you concerning $\mathrm{p}$ ? An epistemic peer is someone whom you judge to be as rational, intelligent, and unimpaired as you and to have the same evidence as you (see, e.g., Christensen 2009, 2). Feldman (2006), Elga (2007), and Christensen (2007) have defended a conciliatory principle:

Equal Weight $\quad$ One should give the credences of epistemic peers as much consideration as one's own credences. ${ }^{1}$

Giving the credences of one's epistemic peers the same consideration as one's own means that one's credences conditional on meeting an epistemic peer and learning of disagreement should be halfway between the peer's and one's own prior credences; this commits one to shifting one's credences halfway towards those of one's epistemic peer when one learns of the disagreement. ${ }^{2}$ There are a number of ways one could disagree with Equal Weight. One is Extra Weight, the view that one should give one's own credences greater consideration than one's peer's (Elga 2007, 485). Another is the Total Evidence view, which says that one may give one's own credences greater consideration than one's peer's to the extent that one has good reasons for doing so (Kelly 2010). I will consider the following claim (called "The No Independent Weight View" in Kelly 2010), which is compatible with both Extra Weight and the Total Evidence view:

Steadfastness One's credence in $\mathrm{p}$ after learning that an epistemic peer disagrees may equal one's prior credence in $p$.

There is not space in this paper to arbitrate conclusively the debate between Equal Weight and Steadfastness. However, it will be important to consider briefly motivations that have been advanced for these views.

\section{Motivations for Equal Weight and Steadfastness}

A common consideration given in favor of Equal Weight (Christensen 2007, 190-92) is that for me not to give my epistemic peer's credences equal weight involves an arbitrary privileging of my own credences. In recognizing that someone is my epistemic peer, I am

\footnotetext{
${ }^{1}$ Elga (2010) admits that this principle is strictly speaking self-undermining, because those who endorse it are compelled by it to conciliate their opinions with those who oppose it, and thus would come to no longer endorse it. He modifies Equal Weight by specifying that it does not apply to cases of disagreement about disagreement, and argues that this modification is not ad hoc. My arguments in this paper apply to both Equal Weight and to Elga's modification of it.

${ }^{2}$ In a full belief context, if you peer believes that $p$, and you believe that not- $p$, then Equal Weight would have you both adopt an agnostic attitude. It is not clear what you ought to do if one party is agnostic and the other believes or disbelieves.
} 
taking her to have evidence and reasoning skills equivalent to my own. Epistemologically, there is no difference between the two of us. The only difference is that $I$ am $m e$ - but this hardly seems to be epistemically relevant unless the disputed proposition is related to my private experiences. The kind of example that best fits this motivation for Equal Weight is illustrated by Christensen's restaurant tab case $(2007,193)$. I judge you to be my epistemic peer. We go out to dinner and, as is my habit, I calculate my portion of the bill in my head. I then come to have a high credence in the proposition that my share is $\$ 43$. If I learn that you have mentally calculated my share and have arrived at $\$ 45$, it seems plausible that I should lower my credence in the proposition that my share is $\$ 43$.

An important consideration in favor of Steadfastness is that following Equal Weight looks to make us "spineless." Given the apparent diversity of disagreement in the world, even among epistemic peers, it seems that following Equal Weight would have the effect of rendering us agnostic about any controversial issue whatsoever (Elga 2007, 484-85; Feldman 2007, 213). Moreover, if we assign equal weight to our epistemic peers, then our beliefs will be more affected the more peers there are who disagree with us. This threatens to reduce inquiry into controversial matters into aggregating the opinions of our peers, i.e., into voting (Elga 2007, 484-85; for some absurd consequences of this, see Pettit 2006).

Equal Weight seems more plausible than Steadfastness in "shallower" cases such as the restaurant example, where the disagreement does not affect many other aspects of our view about the world, while Steadfastness seems more plausible in "deeper" cases such as debates about the divinity of Jesus, where the disagreement about the proposition in question affects our worldview greatly. This has led some (Elga 2007, 492-94) to develop a version of the Equal Weight view where we are not required to modify our beliefs upon learning about deep disagreement (for example, by holding that in these cases, we don't consider those with whom we disagree to be our epistemic peers), and others (Kelly 2010, 168 ) to endorse views opposed to Equal Weight which nonetheless allow for meeting peers halfway in certain specified circumstances.

\section{The Equal Weight argument against exclusivism}

In the literature on religious diversity, there is a common epistemic argument used by pluralists against exclusivists. ${ }^{3}$ The basic outline of this argument is that exclusivists are committing an error because they are in a symmetrical epistemic position relative to people of other faiths, yet they make the asymmetrical claim that truth resides with their own religion. In this section, I explicate this argument in terms of the Equal Weight view.

The Equal Weight view has implications for a person's probabilities conditional on disagreement with an epistemic peer. An epistemic peer is someone who shares the same evidence and has the same inferential abilities. In the case of religion - or in any realistic case involving complex beliefs - it seems unlikely that two agents would share exactly

\footnotetext{
${ }^{3}$ This argument applies to inclusivists as well; for ease of discussion, I restrict my discussion to the debate between pluralists and exclusivists.
} 
the same evidence. Still, let us consider such a case. This would most plausibly involve, say, two scholars of different religions who have studied the religion of the other, neither of whom have had mystical experiences. According to Equal Weight, their probability conditional on disagreement with an epistemic peer should take into account their prior credence and their peer's prior credence equally.

This constitutes an argument against religious exclusivists. The argument runs: there are people of other faiths who have heard all of your arguments - and, if you have inquired in these matters, whose own arguments you know - and have come to different conclusions. According to Equal Weight, your probabilities, conditional on discovering such disagreement, should take your views and those of your peers into equal consideration, resulting in belief that is moderate between your two prior unconditional probabilities. Given the great number of informed and reflective people in the world of all different faiths, you should - after learning of all of this -modify your credence such that you assign equal probabilities to the world's major religions. Perhaps you would then become confident in whatever is common among these religions and agnostic about the aspects in which they are inconsistent; develop an interpretation of religious claims according to which the apparently inconsistent claims of various religions are all true; or embrace a Kantian understanding of religious language such that the claims of various religions are phenomenally true and noumenally false. This kind of reasoning is evident in several critiques of exclusivism; see, for example, Stenmark (2006, 110-11), Ward (2000, 120), and Plantinga's explication of his opponent's view (2000a, 181). In addition, McKim (2001, 181-83) and Basinger (2000, 46-47) use Equal Weight-style considerations to motivate the claim that exclusivists have an epistemic obligation to re-evaluate their religious beliefs in light of religious disagreement.

\section{Exclusivist attempts to limit Equal Weight}

The exclusivist has been subjected to the critique that she is adopting an asymmetrical attitude - that she is correct and her religious disputants are incorrect - when she is in a symmetrical epistemic situation - viz. all parties are equally grounded in the evidence. Exclusivists might object to this argument on the grounds that the Equal Weight principle does not apply in cases of religious disagreement because the disputants are not epistemic peers. In this section, I survey a number of ways that exclusivists might support this claim. Some may argue that disputants in religious disagreements are unlikely to share a body of evidence because of limitations on human knowledge and the complexity of different religious doctrines. Others may claim that the disputants are guaranteed not to share a relevant body of evidence because religious belief is basic or based on religious experience. Finally, it may be argued that disputants of different faiths would not be epistemic peers because they have radical differences in core beliefs or because people of some faiths are simply not rational. I reject all of these attempts to maintain that Equal Weight does not apply to religious disputes. I conclude that the only hope for exclusivists is to reject the Equal Weight principle itself.

Some might complain that it is unlikely that they ever would share a body of evidence with someone of a different faith. Indeed, they could guarantee the lack of shared 
evidence by never learning anything about other religions! If people of one faith are not epistemic peers with anyone of a different faith, then Equal Weight cannot be used to push their credence away from a commitment to the truth of their own religion over others.

However, there is no refuge to be found here. First, Equal Weight has challenging consequences for exclusivists even if we restrict its application to intrareligious disagreement (King 2008, 847). There is significant disagreement within each religion, even about fundamental issues related to it. To follow the Equal Weight principle would be to prevent oneself from holding very many distinctive positions at all about one's own religion, unless one simply conformed one's credences to the deliverances of an expert (see Elga 2007, 479f; Thune 2010, 720f). Second, it is not far-fetched to think that one might be subject to the experience of having a coreligionist convert to another faith and then share with one the crucial aspects of that other faith which fueled the decision to convert. Third, the conclusion of the Equal Weight argument is that one's current probabilities conditional on meeting an epistemic peer and learning of disagreement should give that person's opinion the same weight as one's own. In other words, conciliation should already be built into one's current conditional probabilities, even if one has not yet met a disagreeing peer. Of course, one could conform to Equal Weight, possess a high credence in one's faith, and have a lower probability in one's faith conditional on running into religious peer disagreement while hoping or trying to guarantee that one never does so. I would imagine that for most exclusivists, such an admission is already a step too far: it would be to say "I' $m$ committed to the exclusive truth of my faith; I love my God and only my God...unless, of course, I ever happen to meet an epistemic peer from a different faith." Yet against those willing to embrace this awkward combination of conditional conciliation with exclusivism, more work must be done.

Willful ignorance can be addressed rather easily. Consider a person who is willing to stick his head in the sand, as it were, and refuse to learn any evidence supporting faiths other than his own. This person is guilty of ignoring evidence, which, while not a violation of the Equal Weight principle, is an epistemic shortcoming. What about those who just happen not to learn of other religions? I claim that such people cannot avoid the Equal Weight argument because the Equal Weight principle can be extended farther than its apparent range of application when combined with principles concerning testimony and expert opinion. In each religion, there are experts who know a great deal about the evidence for and the nature of their own faith. Their statements carry epistemic weight to their coreligionists. Some of these experts know a great deal about other faiths. Thus these experts have epistemic peers in those other faiths; by Equal Weight, they should conciliate. By extension of principles of testimony, the person who doesn't share a body of evidence with people from other faiths should, upon learning that there are experts in his faith who disagree with epistemic peers in other religions, be at least partially conciliatory in his credences (testimony is not infallible, so there wouldn't be a requirement to be fully conciliatory). The fact of religious disagreement and the existence of religious scholars should be enough to inspire conciliation based on Equal Weight, even if one does not personally know any of the details. 
The second way that critics might attempt to reject the application of the Equal Weight principle to cases of religious disagreement is to take issue with the Equal Weight argument's picture of religious disagreement as between epistemic peers with a shared body of evidence. This critique draws on the attempts of scholars who have looked beyond the model of the justification of religious belief based on common evidence in order to defend the rationality of religious belief. Some have argued that religious belief is basic and needs no justification at all (Plantinga 2000b). Others have argued that religious belief can be sufficiently grounded in private religious experience (Alston 1991). Both of these scenarios seem to depart from the Equal Weight argument's picture of epistemic peers disagreeing with a shared body of evidence, the first, because there is no body of evidence, the second, because the body of evidence is not shared. However, a version of the Equal Weight argument can be constructed in both cases.

First, take the case of reformed epistemology. Here, agents do not always infer their warranted beliefs from a body of evidence. Instead, they are warranted in holding basic beliefs without evidence. The Equal Weight principle applies in cases of religious disagreement where the beliefs involved are basic, because in these cases the agents have a shared body of evidence: the null set. Assuming equal inferential abilities, this makes the agents epistemic peers (trivially). Therefore, when they learn of their disagreement, the Equal Weight principle entails that they should conciliate.

Second, consider private religious experience. Technically, the Equal Weight principle does not apply here, because the agents have different bodies of evidence. ${ }^{4}$ However, assuming that their experiences share similar externally verifiable properties (e.g. they are not a result of LSD ingestion), their bodies of evidence are of equal epistemic weight, even though they are not identical. Some kind of extension of the Equal Weight principle might be formulated: that someone counts as your epistemic peer, even if he has different evidence than you have, just in case there is no way of distinguishing between the quality of your respective bodies of evidence. An example might be two agents who share all evidence except that each received different and incompatible testimony from equally trustworthy sources. The same intuitions that motivate Equal Weight would seem to support the claim that such agents should conciliate. Thus, if we are motivated by Equal Weight considerations, it seems we should move our credences towards the credences of those who would be our peers but for having different religious experiences with similar externally verifiable properties. This extension of Equal Weight reasoning to religious experience can be found, for example, in Silver (2001) and Wainwright (2000).

\footnotetext{
${ }^{4}$ To be an interesting epistemic principle, the Equal Weight view must trade on some kind of public verifiability of our evidence: if I see a chair and you see the same chair, we have different private experiences of chairs, but it counts as the same evidence and we are epistemic peers. If Equal Weight did not do so, it would never apply, except perhaps for beliefs about the a priori. Since religious experience is not publically verifiable, religious experience cannot be handled in the same way.
} 
The third way to claim that Equal Weight does not apply to cases of religious disagreement is to claim that all people of other faiths are not epistemic peers in virtue of being less effective evaluators of evidence (see King 2008, 845). I will consider two variants of this argument. The first is based on the claim that any two individuals with significantly different worldviews will ipso facto not regard each other as epistemic peers. Pettit (2006) argues that changing one's belief in propositions "deeply embedded in your credal web" based on disagreement would be disastrous. Elga, a defender of Equal Weight, attempts to avoid this consequence by claiming that individuals who share evidence but disagree on major issues will conclude that the other has consistently failed to draw the correct conclusions from the evidence and is therefore not an epistemic peer. His example is of two individuals who disagree about abortion, and hence who disagree about a host of issues involving, e.g., personhood and early human developmental stages. Elga argues that these individuals will take each other to be unreliable believers in these domains simply on the grounds of their disagreement and therefore will not be epistemic peers $(2007,493)$.

Kornblith responds by arguing that in many cases - including the kind of political disagreement with which Elga's examples are concerned - the agreement between the parties is much more extensive than the disagreement, allowing for epistemic peerhood $(2010,50)$. I maintain that this response also applies to cases of mainstream religious disagreement as well. Even if we bracket off all of the religious points of difference between, say, a Christian and a Buddhist, there will be enough shared religious beliefs such that the two parties have grounds to consider themselves epistemic peers. This will be true of claims about, say, what God is not, what one ought to do, and perhaps particularly about methodological issues. For example, a Christian and Muslim who regard scripture as the literal word of God can agree about the methodological approach to religious questions even though they disagree about which scripture is the word of God. This raises the possibility that peerhood might be delineated by methodological approach (sacred text, mystical experience, rational inquiry) more than religious affiliation. If all of this is correct, shared methodological commitments combined with shared beliefs about the divine are sufficient for two individuals of different faiths to be epistemic peers.

The second way to argue that all people of different religions are less rational evaluators of evidence is to maintain directly that they are less rational humans. I object to this response on the grounds that it is factually incorrect. There is no religion that has cornered the market on rationality. (Of course, there may be a religion that has cornered the market on truth - but that is a different issue.) More precisely, while I think that some characteristics of rationality may vary with religious affiliation - for example, Quakers may have a tendency towards a more thorough consideration of personal testimony than Mormons - it is not the case that a core subset of believers in one religion exhibits greater rationality than the most rational believers of each of the other major religions. Everyone has potential epistemic peers in other religions; given the popularity of interreligious inquiry, it seems certain that everyone has actual epistemic peers as well, subject to the considerations above. 
I conclude that exclusivists cannot plausibly escape the Equal Weight argument by denying that those in other religions are epistemic peers. In order to avoid this argument, they must reject Equal Weight. ${ }^{5}$ In the next section, I argue that they have good company in doing so, for pluralists must reject Equal Weight too. In other words, it is selfundermining for pluralists to use Equal Weight reasoning against exclusivists: the Equal Weight argument against exclusivism, if sound, refutes pluralism as well.

6. Why pluralists need to reject Equal Weight, too

A number of exclusivists have objected to pluralism on the grounds that it is selfdefeating in some way (see Plantinga 2000a; D'Costa 1996; Seeman 2007; Meeker 2003). One way to phrase the objection is that pluralism is not itself a pluralistic doctrine. Another way is to say that pluralism is exclusivist, in that it denies the truth of exclusivism. A third way is: many religions have strong exclusivist strands; pluralism rejects this aspect of religion, which is exclusivist.

The objection that pluralism is self-undermining is hard to pin down, and has met with criticism (Hick 1997; Schmidt-Leukel 2005, 21-22). I think there is good reason for this objection to be critiqued. If we take pluralism as defined above, there is no contradiction to be found. Pluralism is the claim that the world is such that more than one religion has $\mathrm{P}$, with no singular maximum. But to reject the claim that only one religion has $\mathrm{P}$ is not to say that in all areas of human inquiry, it is not the case that one view is correct and inconsistent views are false. Thus, in the domain of responses to religious disagreement, pluralists can maintain that one view is correct (pluralism) and inconsistent views are false (including exclusivism). As has been pointed out (Hick 1997, 162), the objection that pluralism is self-undermining because it excludes exclusivism amounts to the absurd idea that pluralists are not allowed to make any assertoric claims.

To be sure, pluralists have to explain why the apparent inconsistency of their view which prima facie allows that inconsistent claims made by different religions are all true - is merely apparent. But this is a different issue than the accusation that pluralism is inconsistent simply in virtue of rejecting exclusivism.

\footnotetext{
${ }^{5}$ King $(2008,847)$ presents the possibility that religious exclusivists will reject Equal Weight but agree that religious disagreement should result in reduced credence in one's religion. This looks similar in spirit to the views of McKim (2001) and Basinger (2000). There is not space in this article to explore fully this approach. My initial take is that it will be difficult for exclusivists to give away something but not everything. One consideration is the arbitrariness of giving an epistemic peer some but not equal consideration. Another is the risk of having one's credence in one's religion reduced to the level of agnosticism. There is a lot of religious disagreement out there to be had! State a weighting used to calculate how far one should conciliate in cases of disagreement; we can find enough disagreement to force agnosticism. Alternatively, stipulate a maximum level of credence conciliation that can be forced by disagreement; we can find enough disagreement to make the stipulation of that maximum be tantamount to Steadfastness.
} 
While the objection that pluralism is intrinsically self-undermining fails, there is a stronger case to be made for the claim that pluralists' Equal Weight argument against exclusivism is self-undermining. The reason for this is that the universe of epistemic peers disagreeing about religion is larger than peers of different religious faiths. It includes epistemic peers who are agnostics and atheists. This means that pluralists including erstwhile exclusivists convinced by Equal Weight arguments to abandon their exclusivism - will be compelled by Equal Weight to lower their credence in the truth of all religions and raise their credence in the nonexistence of God. "Meeting everyone halfway" will result in a thoroughgoing agnosticism of the sort described by Feldman (2007), not religious pluralism.

It might be objected that there are more religious believers (roughly 5 billion) than atheists and agnostics (roughly 1 billion), and hence that a view weighted equally by the views of one's peers would not end up being agnostic. There are three points to be made here. First, one's probabilities conditional on discovering peers with a wide range of beliefs on religion are highly complex, and it will be hard for either side of this debate to say anything determinate about them. Second, the origins of atheism and agnosticism may make the beliefs of atheist and agnostic peers count more than those of religious peers. To see this, note that if one is faced with disagreement with more than one peer, how one should react depends on how the beliefs of the peers were formed (Elga 2010, 177; Kelly 2010, 146f). Consider again the restaurant case, but suppose that you are dining with ten friends rather than one. Upon returning to the table, you discover that all ten friends are confident that your share is $\$ 45$ rather than the $\$ 43$ that you have calculated. What should you do with your credence? It depends on how your friends arrived at their conclusions! If one of them did the math in her head and shared the answer with the others, who subsequently became confident in her answer, the situation is the same as if you had only one disagreeing peer; by Equal Weight, you should meet the collection of them halfway. However, if all of them performed the calculations separately, then you should meet them $10 / 11$ s of the way towards their position, and thus be almost certain that your share is $\$ 45$. Now, religious belief is often not independently arrived at, as is clear from the fact that most members of a religion are the children of other members of that religion. However, many atheists and agnostics are the children of people of faith. If more atheists and agnostics arrive at their beliefs independently than religious people, then their opinions will generally count more in calculations of how to take disagreement into consideration, and their lesser numbers might be overcome. The third and final point to be made is that even if the above replies are not accepted, the existence of atheist and agnostic peers should at least lower pluralists' confidence in their own view by the same reasoning that the above authors use to critique exclusivists. To the extent that it does so, it is counter-productive.

What about pluralists who started out as atheists or agnostics? It might be argued that such pluralists can consistently critique exclusivists on the basis of Equal Weight considerations because they have already taken atheist or agnostic viewpoints into consideration. Equal Weight does not make you conciliate with viewpoints you have already considered (Elga 2010, 178). However, this point should be stated more precisely: Equal Weight does not require you to conciliate with the viewpoints of people 
whose views (token) you have already considered, but it does require you to conciliate when you learn of new peer disagreement, even if the peers hold views (type) identical to those of people with whom you have already conciliated. Our lapsed atheist will have considered the views of some atheists (including her prior self), but will no doubt run into individuals new to her who have arrived at atheism independently from those she has consulted previously; by Equal Weight, she must conciliate with these individuals.

The final objection I'll consider to the argument that pluralism is undermined by its own Equal Weight argument against exclusivism is that being an atheist or agnostic commits one to a fundamental error in thinking that disqualifies one from being a peer to people of faith. The only way I see this happening is if one of the arguments for the existence of God is both sound and sufficiently obviously sound that the failure to recognize its soundness is irrational. Since the history of philosophy demonstrates that this is not the case, the objection under consideration fails. I conclude that the pluralist argument against exclusivism based on Equal Weight-style considerations undermines pluralism.

\section{Conclusion: Religious permissivism}

I have claimed that an important argument pluralists use against exclusivists is based on Equal Weight-style reasoning; that the only plausible rejoinder on behalf of exclusivists is to reject the Equal Weight principle; and that while the exclusivist complaint that pluralism is self-undermining is incorrect, exclusivists can rightly object that the pluralists' Equal Weight argument against exclusivism is self-undermining, for it pushes pluralists themselves towards agnosticism. Thus both parties have an interest in rejecting Equal Weight - even though for the pluralist it involves abandoning a favored argument against the exclusivist - and embracing Steadfastness. Steadfastness is a view amenable to the exclusivist, for it points to the possibility of her rationally maintaining the unique correctness of her faith despite the existence of peer disagreement.

I conclude by suggesting quite speculatively how those with pluralist motivations might proceed in the absence of Equal Weight. Pluralists have an admirable desire to validate the thinking and beliefs of reasonable people in the area of religion. Those who have chosen to make an epistemic argument against exclusivism and for pluralism based on Equal Weight considerations seek to critique those who think that the beliefs of people of different faiths are incorrect (insofar as they are inconsistent with their own religious beliefs). By doing so, they embrace a principle that puts tight constraints on rationality, threatening to undermine the attempt to validate the thinking and beliefs of reasonable people in the area of religion. This leads to exclusivist complaints that pluralism is a narrow - even intolerant - doctrine (D'Costa 1996). Exclusivists may think that adherents of competing religions are incorrect; but defenders of the Equal Weight argument think that exclusivists are irrational.

I suggest that Epistemic Permissiveness - although it is itself contentious (Feldman 2007; White 2005) - is the principle best suited for the pluralist goal of validating the thinking of reasonable people in the area of religion: 


\section{Epistemic Permissiveness}

There is sometimes more than one rational credence for a given proposition relative to a given body of evidence.

If we endorse Epistemic Permissiveness, learning of disagreement does not always push us towards changing our credences, because in some cases both our opinion and our peer's opinion are within the bounds of what is rational (see Kelly 2010, 118f).

Epistemic Permissiveness alone is not sufficient to validate the thinking of reasonable people in the area of religion. While some who endorse Epistemic Permissiveness may hold that there are often situations in which the range of rational credences relative to a given body of evidence is large, others may hold that it is usually or always very small. Indeed, one could technically be an epistemic permissivist in virtue of holding that in a single context unrelated to religion, there are two rational credences. Therefore, Epistemic Permissiveness is compatible with the most rigid exclusivist and pluralist positions which hold that it is irrational to be anything other than that style of exclusivist or pluralist.

In order to validate the thinking of reasonable people in the area of religion, we must add to Epistemic Permissiveness the claim that the range of rational responses to religious bodies of evidence encompasses some varieties of both exclusivism and pluralism. I will use 'religious permissivism' to refer to the view that (1) Epistemic Permissiveness is true; and (2) some exclusivist and some pluralist attitudes are rational in the light of disagreements about models of God. Religious permissivism operates at a different level from the debate between exclusivism and pluralism. ${ }^{6}$ Thus religious permissivism allows individuals to be exclusivists or pluralists. It is within the bounds of proper belief to hold that one's own religion is correct and others are incorrect; it is also within the bounds of proper belief to hold that there is truth within a multiplicity of religions. An example can be found in Philip Quinn's argument that practitioners of one tradition of mystical experience can rationally respond to the existence of incompatible but apparently equally profound competing traditions by either continuing their practice as is or revising it to incorporate a Kantian understanding of mystical experience along the lines of Hick's pluralism (Quinn 1995). Note that, just as pluralists do not have to endorse all forms of religious thought, religious permissivism does not have to license as rational all varieties of opinion on religious disagreement. For example, a religious permissivist could argue that certain forms of soteriological exclusivism are irrational.

Developing and defending religious permissivism would require extensive additional investigation. I'll close by mentioning a reason for thinking that religious permissivism is worth the effort. This reason is based on an analogy to the philosophy of science (see, e.g.,

\footnotetext{
${ }^{6}$ Hick holds that "religious exclusivism and religious pluralism are of different logical kinds, the one being a self-committing affirmation of faith and the other a philosophical hypothesis" (1997, 163; see also Meeker 2006, Hick 2006). Hick is thinking of exclusivism, not as the philosophical hypothesis that exactly one religion mediates knowledge of ultimate reality, but rather as the faith in that religion. I continue to conceive of exclusivism and pluralism as philosophical hypotheses.
} 
Axtell 2003, Gutting 1982). Lakatos holds that it is best for science to support multiple research programs. Diversifying our epistemic portfolio is the best way to make progress on difficult problems. Perhaps no problem is more difficult than the investigation of divinity. One virtue of religious permissivism is that it validates the rationality of a multiplicity of approaches, including exclusivist approaches, to flourish. There may be significant epistemic utility in there being entrenched exclusivists of various religions, as well as individuals who attempt to find common ground among world religions. It would be a bad thing for us to lose this diversity of approaches to religious disagreement; doing so might undermine our attempts to learn more about ultimate reality.

Religious permissivism contains lessons for both exclusivists and pluralists. For exclusivists, the maneuver of denying epistemic peerhood to those of different faiths has been rejected. It has been replaced by an acknowledgement of the rationality of (at least some of) those of different faiths, and of some religious pluralists. ${ }^{7}$ In the end, religious exclusivists are permitted to remain steadfast and maintain their view that their religion is true and other religions are false, but at the same time, they must acknowledge the rationality of different approaches to religious belief. Pluralists must relinquish a common epistemic argument for pluralism, and must acknowledge the rationality of (at least some) exclusivist approaches to religious faith. I think these lessons are useful, as they point towards spending more time on exploring various models of God and less time focusing on the debate between exclusivism and pluralism. ${ }^{8}$

\section{Works cited}

Alston, William. 1991. Perceiving God: The epistemology of religious experience. Ithaca, NY: Cornell University Press.

Axtell, Guy. 2003. Religious pluralism and its discontents. Journal of Indian Philosophy and Religion 8: 49-73.

\footnotetext{
${ }^{7}$ Some permissivists may argue that disagreement with permissivism is beyond the bounds of reasonable belief, giving them the leverage to critique non-permissivists. On this view, religious permissivism would be rationally required; exclusivists would be forced on pain of irrationality to recognize the rationality of some pluralists; and vice versa. However, it is also possible that some permissivists would claim that it is rational not to believe in permissivism. This would make it hard to convince others of the view; however, it would not undermine belief in permissivism. On this latter view, permissivism would not require of exclusivists and pluralists that they regard at least some in the other camp as rational. Although I state the consequences of the former view in the main text, this question requires further investigation.

${ }^{8}$ I am grateful to helpful comments from Jeanine Diller, Brian Kierland, Aaron Smith, and audiences at Boise State University and the 2010 Models of God conference at the American Academy of Religion.
} 
Basinger, David. 2000. Religious diversity: Where exclusivists often go wrong. International Journal for Philosophy of Religion 47: 43-55.

Christensen, David. 2007. Epistemology of disagreement: The good news. Philosophical Review 116: 187-217.

Christensen, David. 2009. Disagreement as evidence: The epistemology of controversy. Philosophy Compass 4: 1-12.

D'Costa, Gavin. 1996. The impossibility of a pluralist view of religions. Religious Studies 32: 223-232.

Elga, Adam. 2007. Reflection and disagreement. Nô̂s 41: 478-502.

2010. How to disagree about how to disagree. In Disagreement, eds. Richard Feldman and Ted A. Warfield, 175-186. Oxford: Oxford University Press.

Feldman, Richard. 2006. Epistemological puzzles about disagreement. In Epistemology futures, ed. Stephen Hetherington. Oxford: Oxford University Press, 216-36.

. 2007. Reasonable religious disagreements. In Philosophers without gods: Meditations on atheism and the secular life, ed. Louise Antony, 194-214. Oxford: Oxford University Press.

Gutting, Gary. 1982. Religious belief and religious skepticism. West Bend, In.: Notre Dame Press.

Hick, John. 1997. The possibility of religious pluralism: A reply to Gavin D'Costa. Religious Studies 33: 161-66.

2005. The next step beyond dialogue. In The myth of religious superiority: $A$ multi-faith exploration, ed. Paul Knitter, 3-12. New York: Orbis Books.

2006. Exclusivism versus pluralism in religion: a response to Kevin Meeker. Religious Studies 42: 207-212.

Kelly, Thomas. 2005. The epistemic significance of disagreement. In Oxford Studies in Epistemology, vol. I, eds. Tamar Szabó Gendler and John Hawthorne, 167-96. Oxford: Oxford University Press. . 2010. Peer disagreement and higher-order evidence. In Disagreement, eds. Richard Feldman and Ted A. Warfield, 111-74. Oxford: Oxford University Press.

King, Nathan L. 2008. Religious diversity and its challenges to religious belief. Philosophy Compass 3/4: 830-853. 
Kornblith, Hilary. 2010. Belief in the face of controversy. In Disagreement, eds. Richard Feldman and Ted A. Warfield, 29-52. Oxford: Oxford University Press.

McKim, Robert. 2001. Religious ambiguity and religious diversity. Oxford: Oxford University Press.

Meeker, Kevin. 2003. Exclusivism, pluralism, and anarchy. In God matters: Readings in the philosophy of religion, eds. Raymond Martin and Christopher Bernard, 524-34. New York: Longman.

. 2006. Pluralism, exclusivism, and the theoretical virtues. Religious Studies 42: 193-206.

Pettit, Philip. 2006. When to defer to majority testimony - and when not. Analysis 66: $179-87$.

Plantinga, Alvin. 2000a. Pluralism: A defense of religious exclusivism. In The philosophical challenge of religious diversity, eds. Philip L. Quinn and Kevin Meeker, 172-92. Oxford: Oxford University Press.

. 2000b. Warranted Christian belief. Oxford: Oxford University Press.

Quinn, Philip L. 1995. Towards thinner theologies: Hick and Alston on religious diversity. International Journal for Philosophy of Religion 38: 145-64.

Schmidt-Leukel, Perry. 2005. Exclusivism, inclusivism, pluralism: The tripolar typology — clarified and reaffirmed. In The myth of religious superiority: A multifaith exploration, ed. Paul Knitter, 13-27. New York: Orbis Books.

Seeman, Bradley N. 2007. Verifying pluralism: A thought experiment regarding pluralism's exclusivisms and the question of tolerance. Philosophia Christi 9: 121-43.

Silver, David. 2001. Religious experience and the facts of religious pluralism. International Journal for the Philosophy of Religion 49: 1-17.

Stenmark, Mikael. 2006. Exclusivism, tolerance and interreligious dialogue. Studies in Interreligious Dialogue 16: 100-14.

Thune, Michael. 2010. Religious belief and the epistemology of disagreement. Philosophy Compass. 5/8: 712-724.

Ward, Keith. 2000. Truth and the diversity of religions. In The philosophical challenge of religious diversity, eds. Philip L. Quinn and Kevin Meeker, 109-25. Oxford: Oxford University Press. 
Wainwright, William J. 2000. Religious experience and religious pluralism. In The philosophical challenge of religious diversity, eds. Philip L. Quinn and Kevin Meeker, 218-225. Oxford: Oxford University Press.

White, Roger. 2005. Epistemic permissiveness. Philosophical Perspectives 19: 445-459. 